\title{
INTERPRETATION, ENFORCEMENT AND IMPLEMENTATION
}


Carlos M. Correa - 9781849806602 Downloaded from PubFactory at 04/26/2023 12:26:46PM via free access 